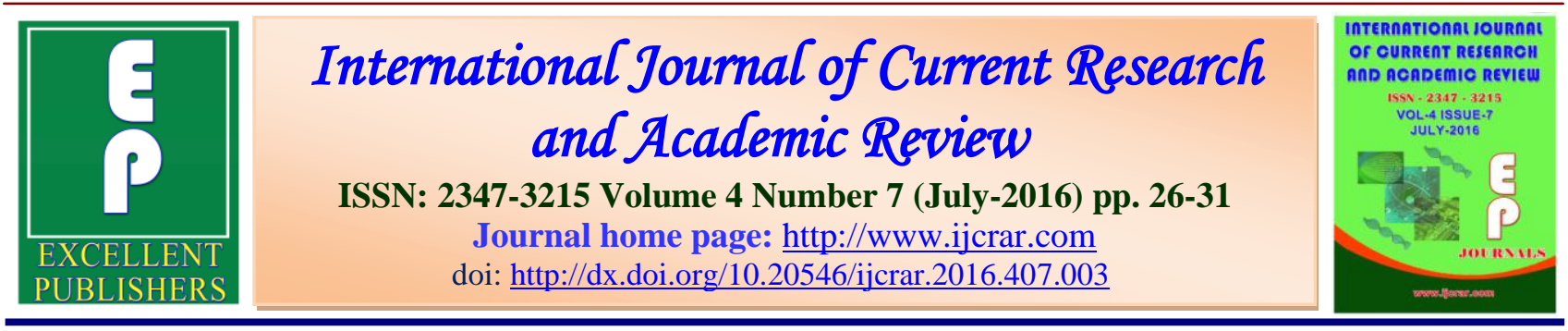

\title{
Ficus auriculata; A Pharmacological Update
}

\author{
Mathew George, Lincy Joseph and Nimisha M. Paul*
}

Pushpagiri College of Pharmacy, Thiruvalla-689107, Kerala, India

*Corresponding author

\begin{tabular}{|l|l|}
\hline \multirow{2}{*}{$\begin{array}{l}\text { KEYWOS auriculata, } \\
\text { antimicrobial, } \\
\text { antioxidant, } \\
\text { phytochemical, } \\
\text { pharmacological. }\end{array}$} & $\begin{array}{l}\text { A B S T R A C T } \\
\text { phytochemical and pharmacology aspects of Ficus auriculata (Moraceae). } \\
\text { This plant is popular in indigenous system of medicine like Ayurveda, siddha, } \\
\text { Unani and homoeopathy. It is perennial evergreen shrub or small tree that } \\
\text { grows up to12m high. Various plant parts such as bark, root, leaves, fruits and } \\
\text { latex are used in dysentery, diarrhoea, diabetes, stomach ache, piles and as } \\
\text { carminative, astringent and also as antioxidant and anticancer agent. Latex is } \\
\text { widely used for curing warts, skin ulcers and sores, and taken as a purgative } \\
\text { and vermifuge. The phytochemical screening revealed for the presence of } \\
\text { glycosides, flavonoids, phenols, resin and tannins. The fruits contain higher } \\
\text { value of fat, protein, fibreand minerals. The various parts of this plant has } \\
\text { various pharmacological and biological activities. }\end{array}$ \\
\hline
\end{tabular}

\section{Introduction}

Ficus auriculata is a huge tropical, deciduous and evergreen tree with more than 800 species. Bark, root, leaves, fruit and latex of this plant are commonly used for the treatment of various illnesses. Ficus auriculata produces a unique fruit which is actually an inverted flower.

Ficus species are rich source of polyphenolic compounds, flavonoids which are responsible for strong antioxidant properties that help in prevention and treatment of various oxidative stress related diseases such as neurodegenerative and hepatic diseases. Leaves are crushed and the paste is applied on the wounds for curing.
They are also used in treatment of diarrhoea and dysentery. Stem bark juice is very effective for diarrhoea, cuts and wounds. Roasted figs are taken for treating diarrhoea and dysentery. Root latex is used in mumps, cholera, diarrhoea and vomiting. Ficus auriculata has a very tasty fruit. And the fruit is very much liked by all.

The fig is a very juicy fruit. Work should be taken on standardizing the techniques for making various products, such as squash, jam and jelly from this fruit. It contains Bsitosterol, friendelin and epifriedlanal isolation from Egyptian plant. 
A deciduous woody tree, having a short trunk, which soon divides into a few stout laterals, which further- branch irregularly, spreading in all directions; height. 10-12 metres; bark, smooth, grey, with a tinge of yellow or green. Leaves are exstipulate, petiolate, each having an $8.5 \mathrm{~cm}$-long petiole, deciduous, obtuse, cordate, entire to undulate, alternate, $21.5 \mathrm{~cm}$ long, $23.5 \mathrm{~cm}$. broad, having reticulate venation. Flowers are unisexual; inflorescence, hypanthium, both the male and female flowers are borne on the fleshy receptacle; the male flowers, 4 $\mathrm{mm}$ long; the female flowers, $6 \mathrm{~mm}$ long the calyx and the corolla, modified into threadlike scales; stamens, very small, about $2 \mathrm{~mm}$ long; style, long, deeply twobranched; ovary, single, ovoid. Fruit are syconoid, globose, having a 4.5-cm-long stalk, $4.5 \mathrm{~cm}$ in diameter. $30.55 \mathrm{~g}$ in weight, $30.12 \mathrm{ml}$ in volume; the apical opening of the fruit, guarded by scales; mature fruits are yellowish to purple; pulp is light red. The fruit is, in fact, a fleshy receptacle, enclosing a number of true fruits or achenes, which develop from the female flowers lying within this receptacle. Seeds are numerous and are very small. They are eaten along with the fruits. The flowering starts from the first week of March and continues till the end of April. The fruiting season was observed to last from the first week of June to the end of July. The average yield of a tree of Ficus roxburghii Wall. was recorded to be $32.4 \mathrm{~kg}$.

\section{Synonyms}

Ficus roxburghii Wall, Ficus macrophylla Roxb (Khan, 2001).

\section{Selected vernacular names}

English: Elephant ear fig, Roxburgh fig.

Hindi: Fagoora, Phagoora, Tiamble, Timla, Tirmal.

\section{Phytochemical constitution of F. auriculata}

Flavonols contents are (kaempeferol, quercetin, myricetin) were identified. Additionally, betulinic acid, lupeol, stigma sterol, bergapten, scopoletin, $\beta$-sitosterol-3$O-\beta$ - $D$-glucopyranoside, myricetin and quercetin-3- $O-\beta-D$-glucopyranoside were isolated from the petroleum ether, $\mathrm{CHCl} 3$ and EtOAc fractions of alcoholic extracts of the leaves and fruits (Mohamed et al., 2013).

\section{Medicinal uses}

Fresh juice (50-100 ml) of leaves of Ficus racemosa $\mathrm{L}$. is given with water for about 10 days to treat gastrointestinal problems. Bark of Ficus arnottiana and F. hispida showshypoglycaemic activity. Roots of Ficus bengalensis shows anthelmintic activity. The extracts also reported to inhibit insulinase activity from liver and kidney. Fruit extracts exhibits anti-tumour activity. Various pharmacological actions such as anti-ulcer, anti-diabetic, lipid lowering and antifungal activities have been described for F. exasperata. Ethanolic leaf extract of F. exasperata shows anti-bacterial activity. Leaves exhibit hypotensive activity. Ethanolic and aqueous wood extracts of $\mathrm{F}$. glomerata shows Anti-HIV- 1 integrase activity. Ficus religiosa is reported to have numerous therapeutic uses in folk medicine. Leaf juice has been used for the treatment of asthma, cough, sexual disorders, diarrhoea, haematuria, ear-ache and toothache, migraine, eye troubles, gastric problems and scabies; leaf decoction has been used as an analgesic for toothache; fruits for the treatment of asthma, other respiratory disorders and scabies; stem bark is used in gonorrhoea, bleeding, paralysis, diabetes, diarrhoea, bone fracture, antiseptic, astringent and antidote. In Ayurveda it is claimed that Ficus religiosa possesses 
anticonvulsant activity. Many such reports had been validated pharmacologically for its actions on CNS. Different parts of Ficus religiosa showed acetyl cholinesterase inhibitory activity and antianxiety activity. Figs (fruits) of this plant contain numerous amino acids like asparagine and tyrosine in fruit edible part, alanine, threonine, tyrosine and valine in seeds, alanine and valine in proteins. The methanolic extract of figs of Ficus religiosa had anticonvulsant activity. The fruit extracts of $F$. sycomorous L., $F$. benjamina L., $F$. bengalensis $L$. and $F$. religiosa $L$. exhibit anti-tumour activity and anti-bacterial activity, but no anti-fungal activity. Fresh and dried fruit of F. carica is used in cancer, carcinoma, ulcers, hepatomegaly, splenomegaly. Latex is used in ulcers and gout. Leaves are used in cancer, tumours, dermatitis. Latex of F. racemosa is used as aphrodisiac and bark powder is used in diabetes, ulcers, hiccups, gonorrhoea and fruits are used as laxative and digestive. Fruit of F. carica shows spasmolytic activity, mediated through the activation of K+-ATP channels along with anti-platelet activity. Hence, it can be used in gut motility and inflammatory disorders (Sirisha, 2010).

Ficus auriculata Lour. (Ficus roxburghii Wall.) the plant under investigation has been cited in the old literature for its medicinal properties. The juice of this plant was used in diarrhoea followed by warm saline water. In India, the fresh latex was used to treat dental caries. The latex from the stems is applied to cuts and wounds. The roasted fruit is used in the treatment of diarrhoea and dysentery.

\section{Activity studies}

\section{Anti- bacterial and antifungal properties}

The disc diffusion assay methods were used to determine the growth inhibition of bacteria by plant extracts. Diluted bacterial culture $(100 \mu l)$ was spread over nutrient agar plates with a sterile glass L-rod. $10 \mathrm{mg} / \mathrm{ml}$ and $50 \mathrm{mg} / \mathrm{ml}$ of each extracts were applied to each filter paper disc (Whatman No. 1, $5 \mathrm{~mm}$ diam.) and allowed to dry before being placed on the agar plate. Each extract was tested in triplicate (3 discs/ plate) and the plates were inoculated at $37^{\circ} \mathrm{C}$ for $24 \mathrm{~h}$. After incubation, the diameter of inhibition zones was measured with a caliper (Saria Saklani, 2012).

The antifungal activity was tested by disc diffusion method8, 9. The Sabouraud dextrose agar plates were each similarly seeded with each fungal strain The 24 hrs. both culture of each bacterium and 7 days inoculated fungus culture were used to seed sterile Sabouraud dextrose agar at $45^{\circ} \mathrm{C}$ respectively and fungal plates were incubated at $25-28^{\circ} \mathrm{C}$ for 7 days after which diameter of zones of inhibition were measured. Each disc filled with extract.

The Ficus auriculata plant fruit extract has shown anti-bacterial and anti-fungal property.

\section{Nutritional and Mineral content}

The edible portion of fruits was analysed for moisture, ash, fat and fibre. Total nitrogen was analysed by micro-kjeldhal method and for crude protein the value was multiplied by 6.25 . Total carbohydrates were obtained by subtracting the value moisture, crude protein, crude fat crude fibre and ash from $100 \%$. The total energy value equal to addition of fat, protein and sugars calorie, each gram of fat give $9 \mathrm{kcal}$, protein and sugar give $4 \mathrm{kcal}$ energy. The minerals analysed were Potassium using atomic absorption spectrophotometer, Calcium and Phosphorus by flame photometer. Ascorbic acid in fruits was estimated. 
The level of nutrients such as crude protein $5.32 \%$, carbohydrates $27.09 \%$, crude fibre $16.96 \%$ and ash content $3.7 \%$ and minerals as calcium, magnesium, potassium and phosphorus $(1.35, \quad 0.90,2.11$ and $0.28 \mathrm{mg} / 100 \mathrm{gm})$ respectively.

\section{Antioxidant property}

The antioxidant activity is mainly due to the presence of phenolic compounds and hence the bark contains high level of phenolic compounds. The methanol extract of bark also exhibited anti-bacterial activity against Gram positive and Gram negative bacteria. Various researches carried out on F. microcarpa reported the presence of several triterpenoids such as oleanolic acid, rusolic acid, $\alpha$-hydroxy ursolic acid, protocatechic acid and maclinic acid in the fruits, aerial roots and bark. It has been shown that ursolic acid, oleanolic acid and other triterpenoids are efficient protectors against lipid peroxidation and hence these are potent antioxidants. The antipyretic and analgesic action of Ficus microcarpa is due to its antioxidant activity. The aqueous extract of dried bark of Ficus glomerata exhibited dose dependent antioxidant activity, evaluated by site specific and non-site specificantioxidant activity. The extract has shown presence of flavonoids, phenolics, terpenoids, carbohydrates and alkaloids. The antioxidant activity may be attributed to flavonoids and phenolic present in the drug. The antioxidant effect of aqueous extract of the bark of Ficus bengalensis Linn. Root has been evaluated for its free radical scavenging activity, reducing capacity and hydrogen peroxide activity. These studies have shown that the antioxidant properties are mainly due to the presence of phenolic compounds. Leaves possess the strongest antioxidant potential and pulps the weakest one. These facts may be explained by the highest amounts of phenolic compounds occurring in leaves (Veerapur et al., 2007). The antioxidant capacity of phenolic compounds is based on their ability to scavenge free radicals, chelate pro-oxidant metal-ions and to inhibit some enzymes.

\section{Hypocholesterolaemic agent}

The antioxidant effect of aqueous extract of the bark of Ficus bengalensis has been evaluated in hypercholesterolaemic rabbits. Rabbits are made hypercholesterolaemic by feeding cholesterol. As a result, serum cholesterol, triacylglycerol and LDL+VLDL levels are increased. Hypercholesterolemia leads to increased production of oxygen-free radicals (OFR), which exert their cytotoxic effect by causing lipid peroxidation, depress the antioxidant defences. Administration of aqueous extract of the plant to the hypercholesterolaemic rabbits decrease the levels of lipid peroxidation products by scavenging free radicals like superoxide anion, hydroxyl and peroxy radicals. Decreased lipidperoxidation products is due to the increased availability of antioxidants from aqueous bark extract of Ficus bengalensis. Thus, aqueous extract of bark of Ficus bengalensis has antioxidant properties which lowers cholesterol levels (Rimi Shukla et al., 2004).

\section{Hepatoprotective agent}

The methanol extract of the leaves of Ficus carica Linn. has been evaluated for hepatoprotective activity in rats. The test animals when treated with toxic doses of carbon tetrachloride have markedly elevated the levels of serum aspartate aminotransferase, alanine aminotransferase, total serum bilirubin, indicating acute hepatocellular damage. The $\mathrm{CCl} 4$ is converted into reactive metabolite, halogenated free radical by hepatic cytochrome P450s, which in turn covalently 
binds to cell membrane and organelles to elicit lipid peroxidation with subsequent tissue injury. High lipid peroxidation values indicate excessive free radical induced peroxidation. The measurement of lipid peroxide is also a marker of hepatocellular damage. Methanolic extract of leaves of Ficus carica prevent the rise in lipid peroxides, by its antioxidant effect thereby acting as a hepatoprotective. The decrease in lipid peroxides may be due to the antioxidant effect of the extract. A possible mechanism of the F. Carica extract as hepatoprotective may be due to its antioxidant effect or inhibition of cytochrome P450s which impair the bio activation of $\mathrm{CCl} 4$ into their corresponding reactive species.

\section{Anti-inflammatory agent}

The flavonoids and tannins in the methanolic extract are responsible for the anti-inflammatory activity through their effect on oxidative stress and membrane stabilization (Patil et al., 2009).

\section{Conclusion}

Ficus auriculatais an important plant for various pharmacological activity as well as the plant possess high nutritional value. The plant has been traditionally used for treatment of various illness like cuts, wounds, for diarrhoea and dysentery. The plant also possesses antimicrobial activity, antifungal property. It would be worthwhile in continuing research to isolate the active compounds and as well as exploring for its new pharmacological activities.

\section{References}

Burlakoti, C., Kunwar, R.M. 2008. Folk herbal medicines of Mahakali watershed Area, Nepal. In Medicinal
Plants in Nepal: An Anthol. Contemporary Res., pg: 187-193.

Chopra, R.N., et al. 1958. Indigenous Drugs of India, Academic Publisher, Calcutta, 2, 508-674.

El-Fishawy, A. et al. 2011. Phytochemical and pharmacological studies of Ficus auriculata Lour. J. Nat. Prod., 4: 184195.

Khan, S. 2001. Therapeutic plants of the Ayurveda: a review of selected clinical and other studies for 166 species. $J$. Alternative and Complementary Med., 7(5): 405-515.

Kokate, C.K. et al. 33 editions 2005, Pharmacognosy, Nirali Prakashan. Pg.: 108-109.

Krishna Mohan, G., et al. 2007. Hepatoprotective activity of Ficus carica Linn. Leaf extract against carbon tetrachloride induced hepatotoxicity in rats, 15(3), pg.: 162166.

Mohamed, Z.M., Salem, et al. 2013. Antimicrobial activities and phytochemical composition of extracts of Ficus species: An over view. African J. Microbiol. Res., Vol.7(33); pp. 4207-4219.

Sirisha, N. 2010. Antioxidant Properties of Ficus species- A Review. Int. J. Pharm. Tech. Res., Vol.2, No.4, pp 2174-2182.

Parmar, C.M.K., Kaushal. 1982. Ficus roxburghii. p. 35-37. In: Wild Fruits. Kalyani Publishers, New Delhi, India.

Patil, V., et al. 2009. Pharmacognostical studies and evaluation of antiinflammatory activity of Ficus bengalensis Linn. J. Pharm., pg.: 4953.

Rimi Shukla, et al. 2004. Antioxidant activity of aqueous extract of the bark of Ficus bengalensis in hypercholesterolaemic rabbits, J. Ethno pharmacol., 92(1) pg.: 47-51. 
Saria Saklani. 2012. In-vitro antimicrobial activity, Nutritional profile and phytochemical screening of wild edible fruit of Garhwal Himalaya (Ficus auriculata). ISSN 0976-044X. Vol 12, Issue 2, Article-011.

Sherif Mahmoud Mohamed Affify. 2012. A Pharmacognostical study of Ficus auriculata Lour. (Family Moraceae) cultivated in Egypt.
Veerapur, V.P., et al. 2007. Ficus racemosa stem bark extract: A potent antioxidant and a probable radio protector, Advance Access Publication. Pg.: 317324.

Ventakamaran, K. 1972. Wood phenolics in the chemotaxonomy of the Moraceae. Photochem., 11: 153-156.

\section{How to cite this article:}

Mathew George, Lincy Joseph and Nimisha M. Paul. 2016. Ficus auriculata; A Pharmacological Update. Int.J.Curr.Res.Aca.Rev.4(7): 26-31. doi: http://dx.doi.org/10.20546/ijcrar.2016.407.003 